\title{
Effective yttrium based coating for steel interconnects of solid oxide cells: Corrosion evaluation in steam-hydrogen atmosphere
}

Molin, S.; Persson, Å.H.; Skafte, T. L.; Smitshuysen, A. L.; Jensen, S.H.; Andersen, K.B.; Xu, H.; Chen, M.; Hendriksen, P. V.

Published in:

Journal of Power Sources

Link to article, DOI:

10.1016/j.jpowsour.2019.226814

Publication date:

2019

Document Version

Peer reviewed version

Link back to DTU Orbit

Citation (APA):

Molin, S., Persson, Å. H., Skafte, T. L., Smitshuysen, A. L., Jensen, S. H., Andersen, K. B., Xu, H., Chen, M., \& Hendriksen, P. V. (2019). Effective yttrium based coating for steel interconnects of solid oxide cells: Corrosion evaluation in steam-hydrogen atmosphere. Journal of Power Sources, 440, [226814].

https://doi.org/10.1016/j.jpowsour.2019.226814

\section{General rights}

Copyright and moral rights for the publications made accessible in the public portal are retained by the authors and/or other copyright owners and it is a condition of accessing publications that users recognise and abide by the legal requirements associated with these rights.

- Users may download and print one copy of any publication from the public portal for the purpose of private study or research.

- You may not further distribute the material or use it for any profit-making activity or commercial gain

- You may freely distribute the URL identifying the publication in the public portal 


\title{
Effective yttrium based coating for steel interconnects of solid oxide cells: corrosion evaluation in steam-hydrogen atmosphere
}

\author{
S. Molin ${ }^{1,2}$, Å.H. Persson ${ }^{1}$, T.L. Skafte ${ }^{1}$, A.L. Smitshuysen ${ }^{1}$, S.H. Jensen ${ }^{1}$, K.B. Andersen ${ }^{1}$, \\ H. Xu ${ }^{1}$, M. Chen ${ }^{1}$, P.V. Hendriksen ${ }^{1}$ \\ ${ }^{1}$ Department of Energy Conversion and Storage, Technical University of Denmark, \\ Frederiksborgvej 399, 4000 Roskilde, Denmark \\ ${ }^{2}$ Faculty of Electronics, Telecommunications and Informatics, Gdańsk University of \\ Technology, ul. Narutowicza 11/12, 80-233 Gdańsk, Poland
}

\begin{abstract}
:
This work describes manufacture, analysis and test of a new well conducting corrosion-protection coating that can be applied on steel types with high chromium content. Electrolytic deposition of yttrium salts is used to form thin $(<100 \mathrm{~nm})$ coatings on both flat steel sheets (material: Crofer 22 APU) and its properties are proven on woven wire-meshes (materials from two different sources: SUS316 and SUS316L). The oxide scale on the coated Crofer 22 APU sheet remains intact after 2000 hours operation at $750{ }^{\circ} \mathrm{C}$ in $\mathrm{H}_{2}$ with $90 \% \mathrm{H}_{2} \mathrm{O}$. The corrosion rate at $750{ }^{\circ} \mathrm{C}$ of the coated Crofer 22 APU sheets is compared with that of uncoated samples and of samples with a commercial magneton sputtered CGO coating revealing that the coatings reduce the parabolic rate constant characteristic of the corrosion by a factor of 10 and 20 for the CGO and the $\mathrm{Y}$, respectively.

The coated meshes also exhibit high corrosion resistance and long-term-stable low electrical resistance at $650{ }^{\circ} \mathrm{C}$, both in $90 \% \mathrm{H}_{2} \mathrm{O}$ in $\mathrm{H}_{2}$, and in air. In addition to the experimental work, $\mathrm{Y}-\mathrm{Cr}-\mathrm{O}_{2}$ phase diagrams are constructed illustrating the high stability of the $\mathrm{YCrO}_{3}$ phase (that forms during corrosion) over a wide temperature and $\mathrm{pO}_{2}$ range.
\end{abstract}

Keywords: Crofer 22 APU; SOEC; SOFC; high temperature corrosion; protective coatings; electrodeposition; 


\section{Introduction}

High temperature corrosion of interconnects (ICS) constitute an important and inevitable degradation source of solid oxide cell stacks [1-4]. Corrosion studies on different alloys have been performed, in particular for the air/oxygen side $\left(\right.$ high $\left.\mathrm{pO}_{2}\right)$ of the ICs $[5,6]$. Though the $\mathrm{pO}_{2}$ level in the hydrogen electrode compartment might seem low $\left(10^{-15} 10^{-22} \mathrm{~atm}\right)$, it is still above the oxidation threshold for $\mathrm{Cr}$ and thus $\mathrm{Cr}_{2} \mathrm{O}_{3}$ will form. Growth of a relatively poorly conducting chromium-oxide scale on the hydrogen side is thus thermodynamically inevitable. Corrosion rates (oxide scale growth rates) are in fact relatively similar in oxidizing and reducing conditions at typical stack temperatures of $700{ }^{\circ} \mathrm{C}-900^{\circ} \mathrm{C}[7,8]$. However, most of the corrosion studies performed in hydrogen considered relatively low steam content (3-4\% of steam, which is easily realizable in the lab.). In case of the electrolysis (or considering the outlet of a fuel cell), the steam content might reach up to $90-95 \%$. Therefore, studying steel interconnects corrosion behavior in high steam conditions is of interest since, for the current state-of the art ICs with protective coatings on the oxygen/air- side, corrosion on the hydrogen side might become the lifetime limiting factor. One of the possible solutions to limit extent of corrosion can be the application of protective coatings. This approach has been extensively used for protection of the interconnects on the oxygen side [6,9-14].

The most successful coatings to limit oxide scale growth rate are based on reactive elements, e.g. Y, $\mathrm{Ce}$, La etc. Positive effects of the reactive elements on high temperature corrosion of alloys have been discovered many years ago [15]. Addition of even a small amount of $\mathrm{Y}_{2} \mathrm{O}_{3}$ results in greatly lowered corrosion rates and much better oxide scale adherence. One of the postulated mechanisms for the improved corrosion resistance is the change in the oxidation mechanism. From the predominantly outward growing scale, caused by outward cation diffusion, to anion limited diffusion due to the blocking effect of the large reactive ions located in the grain boundaries. Many different deposition methods were used to deposit reactive element coatings. Riffard et al. have used implantation and dip coating to develop an $\mathrm{Y}_{2} \mathrm{O}_{3}$ coating on 304 and FeCrAl alloys [16-18]. Piccardo et al. studied $\mathrm{La}_{2} \mathrm{O}_{3}, \mathrm{Y}_{2} \mathrm{O}_{3}$ and $\mathrm{Nd}_{2} \mathrm{O}_{3}$ layers deposited by Metal-Organic Chemical Vapor Deposition (MOCVD) on Crofer 22 APU steel [19]. Samples were tested in air for 100 hours. Gil et al. evaluated $\mathrm{Y}_{2} \mathrm{O}_{3}$ layers prepared by implantation, dip-coating and electrolytic deposition $[20,21]$. Coated alloys were subjected to cyclic oxidation in air at $900{ }^{\circ} \mathrm{C}$. Tondo et al. electrodeposited yttria/cobalt oxide and yttria/gold coatings onto 430 steel and tested them in air for $500 \mathrm{~h}$ at $800{ }^{\circ} \mathrm{C}$ [22]. In all these cases, addition of thin $\mathrm{Y}$ layers on the surface resulted in lowered corrosion rates. Some results have shown poor electrical properties of the $\mathrm{Y}_{2} \mathrm{O}_{3}$ coating [19], most probably caused by the insulating nature of yttria. High temperature fuel cell relevant publications studied $\mathrm{Y}$-coated alloys in air, 
whereas tests in reducing atmosphere (humidified hydrogen) and at reduced temperatures are still an unexplored area.

Among many available ceramic deposition methods, electrolytic deposition offers important advantages for thin film deposition, especially when used with metallic, electrically conductive substrates $[21,23,24]$. As the deposition process is electrically driven, surface coverage by the coating is good and can be done in minutes. Electrolytic deposition (cathodic electrodeposition) works by hydrolysis of yttrium complexes on electrode surfaces to form yttrium hydroxide deposits, which can be converted to an oxide by thermal treatment $[25,26]$. In comparison to the sputtering deposition, which is a line of sight process which can be problematic for coating "hidden" surfaces, electrolytic deposition offers a clear advantage of coating even recessed channels and "hidden" features. The deposition process is also very efficient, as there is no loss of material caused by coating unwanted areas (as is the case for many spraying techniques). Depending on the particular method, water based, environmentally friendly solutions are also feasible. Though several reports exists on electrolytic deposition of ceria or yttria coatings for protection of steel at high temperatures [23-25], none of the studies have addressed the corrosion behavior in reducing atmospheres. Especially at low temperatures $\left(\mathrm{T}<750^{\circ} \mathrm{C}\right.$ as typical targeted for operating state of the art SOFC/SOEC cells), there is a scarcity of reports about corrosion properties in general [27-29]. Relevant available data gathered from literature on corrosion behavior in reducing environment are summarized in Table 1.

Table 1. Literature review - coatings for the hydrogen side of the ICs.

\begin{tabular}{|c|c|c|c|c|c|c|}
\hline No: & Coating: & Steel: & Atmosphere: & Temp: & Refs. & Note: \\
\hline 1 & $(\mathrm{La}, \mathrm{Sr}) \mathrm{CrO}_{3}$ & DIN50049 & $\begin{array}{c}\mathrm{Ar}-\mathrm{H}_{2}-\mathrm{H}_{2} \mathrm{O} \\
\left(\mathrm{pH}_{2} / \mathrm{pH}_{2} \mathrm{O}\right. \\
94 / 6)\end{array}$ & $800^{\circ} \mathrm{C}$ & [30] & $\begin{array}{c}300 \mathrm{~h}, \mathrm{k}_{\mathrm{p}}=8.4 \times 10^{-16} \mathrm{~g}^{2} \mathrm{~cm}^{-4} \\
\mathrm{~s}^{-1}\end{array}$ \\
\hline 2 & $(\mathrm{La}, \mathrm{Sr}) \mathrm{MnO}_{3}$ & Crofer 22 APU & $\begin{array}{c}\text { pure } \mathrm{H}_{2} \mathrm{O}, 30 \\
\text { bar }\end{array}$ & $800^{\circ} \mathrm{C}$ & [31] & $\begin{array}{c}\text { high pressure test in pure } \\
\text { steam }\end{array}$ \\
\hline 3 & $(\mathrm{La}, \mathrm{Sr}) \mathrm{MnO}_{3}$ & AISI 441 & & & [32] & $3000 \mathrm{~h}$ \\
\hline 4 & $\mathrm{La}(\mathrm{Ni}, \mathrm{Fe}) \mathrm{O}_{3}$ & AISI 441 & & & [33] & the same as 3 \\
\hline 5 & $\mathrm{CeO}_{2}$ & Crofer 22 APU & $\mathrm{Ar}-4 \mathrm{H}_{2}-2 \mathrm{H}_{2} \mathrm{O}$ & $800^{\circ} \mathrm{C}$ & [34] & $\begin{array}{l}1000 \text { h test, sputtered } \\
\mathrm{CeO}_{2} \text {, inhibition of the } \mathrm{Ni} \\
\text { diffusion to the alloy }\end{array}$ \\
\hline 6 & $\mathrm{CeO}_{2}$ & Crofer 22 APU & $\mathrm{N}_{2}-9 \mathrm{H}_{2}-4 \mathrm{H}_{2} \mathrm{O}$ & $800^{\circ} \mathrm{C}$ & {$[28,35]$} & $\begin{array}{l}\text { spray pyrolysis deposition } \\
\text { and } 1000 \mathrm{~h} \text { test }\end{array}$ \\
\hline 7 & $\mathrm{Ni}$ & Crofer 22 APU & $\mathrm{N}_{2}-9 \mathrm{H}_{2}-4 \mathrm{H}_{2} \mathrm{O}$ & $800^{\circ} \mathrm{C}$ & {$[36,37]$} & $\begin{array}{c}1000 \mathrm{~h} \text { test, electroplated } \\
\mathrm{Ni}\end{array}$ \\
\hline 8 & $\mathrm{Ni}$ & Crofer $22 \mathrm{H}$ & $\begin{array}{l}\mathrm{Ar}-4 \mathrm{H}_{2-}^{-} \\
10 \mathrm{H}_{2} \mathrm{O} \\
\end{array}$ & $700{ }^{\circ} \mathrm{C}$ & [38] & $\begin{array}{c}500 \mathrm{~h} \text { test, focus on phase } \\
\text { transformations }\end{array}$ \\
\hline 9 & $\mathrm{Ni}$ & $\mathrm{Fe} 22 \mathrm{Cr}$ & $9 \mathrm{H}_{2}-\mathrm{Ar}$ & $850^{\circ} \mathrm{C}$ & [39] & $\begin{array}{c}1200 h \text { test, effects of } \\
\text { temperature also studied } \\
\text { for short term }\end{array}$ \\
\hline 10 & $\mathrm{Ni}$ & $\mathrm{Fe} 22 \mathrm{Cr}$ & $\mathrm{H}_{2}-\mathrm{N}_{2}$ & $850^{\circ} \mathrm{C}$ & [40] & one year test \\
\hline
\end{tabular}




\begin{tabular}{|c|c|c|c|c|c|c|}
\hline 11 & - & Crofer 22 APU & $\mathrm{H}_{2}-50 \% \mathrm{H}_{2} \mathrm{O}$ & $800^{\circ} \mathrm{C}$ & {$[41]$} & $\begin{array}{c}4500 \mathrm{~h}, \text { test of porous } \\
\text { alloy }\end{array}$ \\
\hline 12 & - & $\begin{array}{c}\text { Crofer 22 } \\
\mathrm{APU} / \mathrm{H}, 441, \\
\mathrm{CFY}\end{array}$ & $\begin{array}{c}50 \mathrm{H} 2- \\
50 \mathrm{H}_{2} \mathrm{O}\end{array}$ & $\begin{array}{c}725- \\
875^{\circ} \mathrm{C}\end{array}$ & {$[42]$} & test at high temperatures \\
\hline 13 & - & $\begin{array}{c}\text { Inconel625/718, } \\
\text { Haynes230, } \\
\text { HastelloyX }\end{array}$ & $\mathrm{H}_{2}-7 \% \mathrm{H}_{2} \mathrm{O}$ & $\begin{array}{c}750- \\
1100{ }^{\circ} \mathrm{C}\end{array}$ & {$[43]$} & $\begin{array}{c}\text { test of Ni based alloys, } \\
\text { wide temperature range }\end{array}$ \\
\hline
\end{tabular}

This work describes an yttria based coating deposited by electrolytic deposition and a sputtering deposited CGO coating on stainless steel samples. The paper is organized as follows. The samples used for testing are first described. Then the deposition method is explained. After this, the weight gain data of steel sheet samples tested for 2000 hours in high steam hydrogen is provided. Selected sheet samples are then analyzed with respect to the phases formed by X-ray diffractometry and microstructurally using scanning electron microscope on surfaces and polished cross-sections. Kinetic parameters of corrosion are determined by microstructural analysis of samples and compared between uncoated and ceria coated samples. Further, conductivity tests of uncoated and Y-coated SUS316 and SUS316L wire mesh samples are provided (the measurements are conducted "across the mesh", meaning that the measured resistance contains contributions from the oxide scales formed on the surface of the mesh wires). Finally, a thermodynamic assessment of the $\mathrm{Y}-\mathrm{Cr}-\mathrm{O}_{2}$ system is developed and discussed. 


\section{Experimental}

\section{Sample types}

Three sample types were prepared for the corrosion experiments: 1) uncoated and 2) Y-coated Crofer 22 APU (steel name abbreviated as Cr22APU) alloy steel sheets (thickness $=0.3 \mathrm{~mm}$, area $\sim 1 \times 1 \mathrm{~cm}^{2}$ ), and 3) CGO coated samples (a commercial coating) cut from a larger Crofer 22 APU steel sheet. The CGO coating procedure is described in [44-46]. All the sample types were from the same steel sheet batch. In order to hang the samples in the sample holder on a platinum wire (as described in [7]) a small hole ( $1 \mathrm{~mm}$ diameter) was punched through them. For the study, at least 8 samples of each type were prepared. Due to the space limitation in the corrosion furnace, 4 were used for high temperature exposure. After $250 \mathrm{~h}, 1000 \mathrm{~h}$ and $2000 \mathrm{~h}$ of oxidation, one sample was used for post mortem analysis.

For the electrical conductivity experiment, two types of $\sim 1 \times 1 \mathrm{~cm}^{2}$ mesh samples were prepared: 1 ) SUS316 twill-woven wire meshes from Anping Jiufu Metal Wire Mesh Co. Ltd., and 2) SUS316L plainwoven wire meshes from Hebei Haocheng Metal Wire Mesh Co.,Ltd. Both meshes had 500 wires/inch. Two different producers were included for ensuring reproducibility - important for practical use of the coatings. The sample types are summarized in Table 2 and the Y-coating procedure is detailed below.

Table 2. Sample types for corrosion testing (upper three) and conductivity testing (lower two).

\begin{tabular}{|c|c|}
\hline Sample ID: & Info: \\
\hline $\begin{array}{l}\text { Uncoated } \\
\text { Cr22APU }\end{array}$ & Crofer 22 steel sheet uncoated reference sample \\
\hline $\begin{array}{l}\text { Y-coated } \\
\text { Cr22APU }\end{array}$ & $\begin{array}{l}\text { Crofer } 22 \text { steel sheet coated with }<100 \mathrm{~nm} \mathrm{Y}_{2} \mathrm{O}_{3} \\
\text { prepared by electrolytic deposition }\end{array}$ \\
\hline $\begin{array}{l}\text { CGO-coated } \\
\text { Cr22APU }\end{array}$ & $\begin{array}{l}\text { Crofer } 22 \text { steel sheet coated with } 2 \mu \mathrm{m} \mathrm{Ce} e_{1.9} \mathrm{Gd}_{0.1} \mathrm{O}_{1.95} \\
\text { prepared by magnetron sputtering }\end{array}$ \\
\hline $\begin{array}{l}\text { Y-coated } \\
\text { SUS316 }\end{array}$ & $\begin{array}{l}\text { SUS316 twill woven mesh coated with }<100 \mathrm{~nm} \mathrm{Y}_{2} \mathrm{O}_{3} \\
\text { prepared by electrolytic deposition }\end{array}$ \\
\hline $\begin{array}{l}\text { Y-coated } \\
\text { SUS316L }\end{array}$ & $\begin{array}{l}\text { SUS316L plain woven mesh coated with }<100 \mathrm{~nm} \\
\mathrm{Y}_{2} \mathrm{O}_{3} \text { prepared by electrolytic deposition }\end{array}$ \\
\hline
\end{tabular}

Crofer 22 APU steel sheet was used in the as-delivered condition, no polishing or etching was performed before coating and corrosion exposures.

\section{Y-coating procedure}

All the samples were cleaned ultrasonically in ethanol before Y-coating. Electrolytic deposition was carried out using yttrium nitrate ethanol solution (0.05M). Two electrode cells were used for the 
deposition of the yttrium-based layer. The working electrode (WE) was the small alloy sample suspended on a platinum wire (the meshes were held with a tweezer), whereas the counter electrode (CE) was a Crofer 22 APU sheet in a distance of $1 \mathrm{~cm}$ on both sides of the WE. Electrodes were connected to a power supply (Consort). A voltage of $40 \mathrm{~V}$ was then applied between the samples (WE to CE) for 1 minute. This particular procedure was selected after many initial trials. The deposition sample was withdrawn from the container, rinsed with ethanol and dried at room temperature. Finally, the samples were heat treated on a hot plate at $\sim 400{ }^{\circ} \mathrm{C}$ to decompose the nitrates.

\section{Corrosion tests}

High temperature corrosion evaluation of the steel sheet samples was performed in a dedicated corrosion test rig developed for high steam content tests. The samples were suspended on a platinum wire on a small tubular alumina holder. After insertion into the furnace, the tube was purged with nitrogen and the samples were heated to the aging test temperature of $750{ }^{\circ} \mathrm{C}$. Then the nitrogen was replaced by a hydrogen and steam mixture $\left(\mathrm{H}_{2} / \mathrm{H}_{2} \mathrm{O}=10 / 90\right)$. The steam was generated by feeding oxygen into the hydrogen in the hot zone of the furnace. Flows of the hydrogen and oxygen were controlled with precision flowmeters (Brooks). Samples were aged under these conditions for respectively 250, 1000 and 2000 hours. At these times the furnace was cooled and one sample of each type was removed for subsequent analysis.

\section{Conductivity tests}

Conductivity tests of the mesh samples were conducted by sandwiching two mesh samples between two Pt meshes to obtain two Pt-mesh/sample-mesh interfaces and one sample-mesh/sample-mesh interface. The samples were heated to $950{ }^{\circ} \mathrm{C}$ in $\mathrm{N}_{2}$, the atmosphere was then switched to $9 \% \mathrm{H}_{2}$ in $\mathrm{N}_{2}$, and temperature reduced to $650{ }^{\circ} \mathrm{C}$ and finally the gas flow was changed to $90 \% \mathrm{H}_{2} \mathrm{O}$ in $\mathrm{H}_{2}$. The measurements were carried out in a button-cell test setup and the electric resistance was measured as the real part of the impedance at $0.9868 \mathrm{MHz}$ using a Solartron 1260 electrochemical interface with $0.033 \mathrm{~V} \mathrm{AC}$ amplitude.

\section{Sample analysis}

Analysis of the samples was performed by X-ray diffractometry (XRD) using Bruker D8 Advance equipped with $\mathrm{CU}_{\mathrm{k} \alpha}$ source and a LynxEye 1D detector. Samples were analyzed at room temperature in a standard Bragg-Brentano $2 \theta$ configuration.

Scanning electron microscopy (SEM) images were taken using either a Hitachi TM3000 (lower magnification) or a Zeiss Supra 35 (higher magnifications) microscope. Energy dispersive X-ray 
spectroscopy (EDS) was performed to determine the chemical composition of samples. Bruker Quantax and Noran Thermo VI systems were used for the Hitachi and Zeiss microscopes, respectively. For the observations, cross-sections were prepared by embedding the samples in the epoxy (Struers EpoFix) and polishing down to $1 \mu \mathrm{m}$ finish.

\section{Thermodynamic phase diagram}

Thermodynamic description of the $\mathrm{Cr}_{2} \mathrm{O}_{3}-\mathrm{Y}_{2} \mathrm{O}_{3}$ system was established using the CALPHAD (CALculation of PHAse Diagrams) method. The work was based on the descriptions of the two binary systems: $\mathrm{Cr}-\mathrm{O}$ by Povoden et al. [47] and $\mathrm{Y}-\mathrm{O}$ by Chen et al. [48], respectively. The Gibbs energy function of $\mathrm{YCrO}_{3}$ was then derived in the present work using the following experimental data: Heat capacity of $\mathrm{YCrO}_{3}$ from Stoppe et al. [49,50], Yokokawa et al. [51], Satoh et al. [52], Kim et al. [53] and Su et al. [54]; heat contents (enthalpy) of $\mathrm{YCrO}_{3}$ from Satoh et al. [52] and Suponitskii [55]; enthalpy of formation for $\mathrm{YCrO}_{3}$ from Suponitskii [55]; equilibrium oxygen pressure for the decomposition reaction of $\mathrm{YCrO}_{3}=0.5 \mathrm{Y}_{2} \mathrm{O}_{3}+\mathrm{Cr}+0.75 \mathrm{O}_{2}$ from Kawamura et al. [56]; and finally the phase diagram data from Ranganathan [57]. Further details on the CALPHAD optimization of $\mathrm{Cr}_{2} \mathrm{O}_{3}-\mathrm{Y}_{2} \mathrm{O}_{3}$ are presented elsewhere [58].

\section{Results and discussion}

\section{Investigation of as-prepared samples}

Surfaces and cross-sections of the as-prepared samples are shown in Figure S1 in Supplementary Information (SI). The surface of the uncoated and Y-coated sample sheets remain rough due to the cold rolling of the steel in the factory. CGO coatings deposited on the alloy makes the surface smoother. In the cross-section, the CGO coating is easily distinguishable, whereas the Y coating, due to its low thickness $(<100 \mathrm{~nm})$ is difficult to see. It is visible in some places where the epoxy delaminated (due to shrinkage during epoxy curing) from the substrate and detached the coating. EDS analysis of the surface clearly reveals the presence of a small amount of $Y$ and CGO on the respective samples. Electrolytic deposition is, as will be demonstrated in this work with the steel meshes, very suitable to coat even complex interconnect geometries.

\section{Evaluation of corrosion kinetics}

The three steel sheet samples were evaluated with respect to their corrosion resistance in hydrogen/steam gas mixtures with high steam content.

For the description of the corrosion kinetics of the interconnect alloys a parabolic rate law is used:

$$
\left(\frac{\Delta m}{A}\right)^{2}=\boldsymbol{k}_{p} \boldsymbol{t}+\boldsymbol{C} \quad \text { [Equation 1] }
$$


where: $\Delta m$ is sample weight gain $[g], A$ is the sample surface area $\left[\mathrm{cm}^{2}\right], k_{p}$ the corrosion rate parameter $\left[\mathrm{g}^{2} \mathrm{~cm}^{-4} \mathrm{~s}^{-1}\right], \mathrm{t}$ is the oxidation time $[\mathrm{s}]$, and $\mathrm{C}$ is an integration constant $\left[\mathrm{g}^{2} \mathrm{~cm}^{-4}\right]$.

Measured weight gains of the samples after different aging times at $750^{\circ} \mathrm{C}$ are shown in Figure $1 \mathrm{~A}-\mathrm{C}$. Data for the selected samples (samples number 03) is presented in Figure 2 D. For the uncoated samples, after $1250 \mathrm{~h}$ large weight changes occurred for the two remaining samples. None of the samples followed the expected parabolic behavior. For the CGO-coated samples, larger weight gain occurred for one of the samples (04). For the $\mathrm{Y}$-coated samples, one sample oxidized heavily (sample 04) whereas the other sample remained with a low weight gain. Based on the weight gain measurements for the most promising samples (sample 03 for all three sample types), a parabolic plot was prepared (Figure $1 \mathrm{E}$ ). Although the samples seem not to follow the parabolic rate law very well, it was nonetheless used in order to obtain kinetic values for comparison. Only the regular weight gain data region has been used for the estimations. The calculated corrosion rates are provided in Table 3. The application of both the CGO and $Y$ coatings seems to result in a lowered corrosion rate. The lowest value is obtained for the $\mathrm{Y}$-coated sample and is $\sim 20 \mathrm{x}$ lower than for the uncoated sample which oxidized heavily.
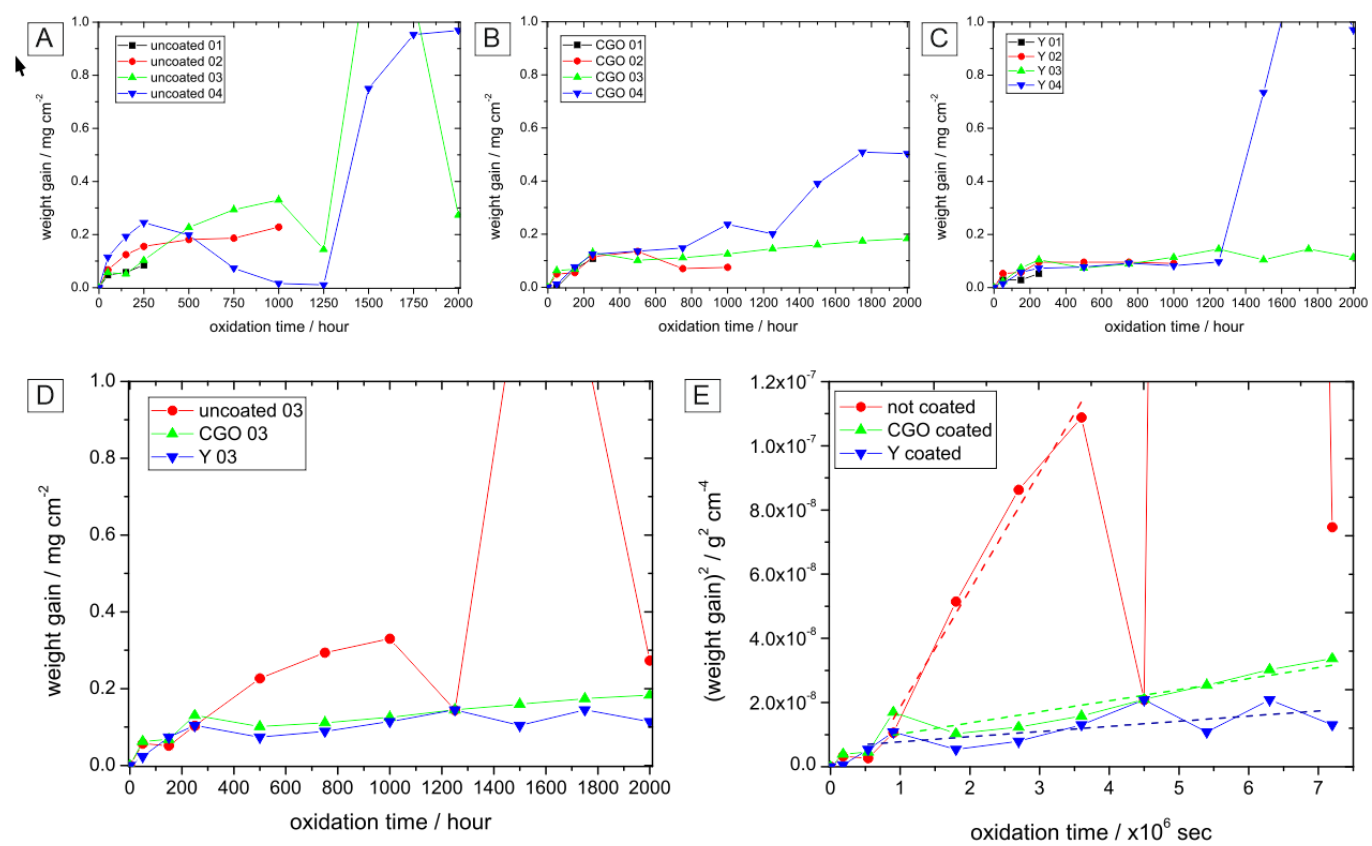

Figure 1. Weight gain data for uncoated (A), CGO-coated (B) and Y-coated samples tested at respectively $250 \mathrm{~h}$ (samples “01"), $1000 \mathrm{~h}$ (samples “02"), and $2000 \mathrm{~h}$ (samples “03" and "04"). Comparison of data for selected samples (D) and quadratic representation of this data (E). The experiment was carried out at $750^{\circ} \mathrm{C}$. 
Corrosion exposures in high steam content $\left(90 \% \mathrm{H}_{2} \mathrm{O} / 10 \% \mathrm{H}_{2}\right)$ at $750{ }^{\circ} \mathrm{C}$ revealed that the uncoated Crofer 22 APU does not "survive" a $2000 \mathrm{~h}$ exposure to this environment. In literature, the number of publications investigating steel corrosion in gases with such a high steam content is limited [[31,42]]. Even more so for investigations on the effects of protective coatings. As presented in Table 1, the majority of the tests were carried out at $800{ }^{\circ} \mathrm{C}$ in different steam contents - in most cases $\sim 4 \%$. In one of the studies [31], pure steam was used, but this is not directly comparable to conditions applied here, as the addition of hydrogen makes the atmosphere much more reducing [31]. GarciaFresnillo has tested uncoated and Ni coated Crofer $22 \mathrm{H}$ sheet in $700{ }^{\circ} \mathrm{C}$ in $\mathrm{Ar}-4 \mathrm{H}_{2}-10 \mathrm{H}_{2} \mathrm{O}$ [38]. The focus of that work was on phase transformations caused by Ni diffusion and no data on corrosion rates was given. Zhang et al. have reported corrosion value of $8.8 \times 10^{-14} \mathrm{~g}^{2} \mathrm{~cm}^{-4} \mathrm{~s}^{-1}$ at $750^{\circ} \mathrm{C}$ in reducing atmosphere $\left(3.75\right.$ vol. $\% \mathrm{H}_{2}+25$ vol. $\% \mathrm{H}_{2} \mathrm{O}+\mathrm{N}_{2}$ ) for a novel Fe-Cr-Mn experimental alloy [59]. Comparing to the available reported results, electrodeposited Y-coating seems to be very effective and promising for further development.

In general, high temperature corrosion rates reported for reducing atmospheres are similar to corrosion rates reported for the air side corrosion [7]. In case of the recent developments of protective coatings for the oxygen side of the interconnects [1], the long term stability limiting interface might become the hydrogen side of the interconnect. Especially in reducing atmospheres with high steam content, measured corrosion rate seems relatively high.

Table 3. Corrosion rates for the three Crofer 22 APU samples (based on data from $[7,60,61]$ ).

\begin{tabular}{|l|c|c|c|}
\hline \multirow{2}{*}{ Sample ID: } & $\begin{array}{c}\text { Corrosion rate } \\
\mathrm{H}_{2} / \mathrm{H}_{2} \mathrm{O}\left(750^{\circ} \mathrm{C}\right):\end{array}$ & $\begin{array}{c}\text { Corrosion rate } \\
\text { Air }\left(750^{\circ} \mathrm{C}\right)\end{array}$ & $\begin{array}{c}\text { Corrosion rate } \\
\text { Air }\left(800^{\circ} \mathrm{C}\right)\end{array}$ \\
\cline { 2 - 4 } & \multicolumn{3}{|c|}{$\left[\mathrm{g}^{2} \mathrm{~cm}^{-4} \mathrm{~s}^{-1}\right]$} \\
\hline $\begin{array}{l}\text { Uncoated } \\
\text { Cr22 APU }\end{array}$ & $3.66 \times 10^{-14}$ & $\sim 5 \times 10^{-15}$ & $6-7 \times 10^{-14}$ \\
\hline $\begin{array}{l}\text { Y-coated } \\
\text { Cr22 APU }\end{array}$ & $1.61 \times 10^{-15}$ & - & $1-2 \times 10^{-14}$ \\
\hline $\begin{array}{l}\text { CGO-coated } \\
\text { Cr22 APU }\end{array}$ & $3.45 \times 10^{-15}$ & - & - \\
\hline
\end{tabular}

\section{Microstructural analysis}

Following the corrosion kinetics evaluation, microstructural post-test analysis of all alloys was performed by using X-ray diffraction and scanning electron microscopy. In order to determine the phase composition of the formed oxides XRD analysis of the sample surfaces was performed. Measured patterns are shown in Figure 2. For the uncoated sample (Figure $2 \mathrm{~A}$ and $\mathrm{D}$ ) up to $1000 \mathrm{~h}$ oxidation, only $\mathrm{Cr}_{2} \mathrm{O}_{3}$ and $\mathrm{Mn}_{1.5} \mathrm{Cr}_{1.5} \mathrm{O}_{4}$ oxides are detected. For the $2000 \mathrm{~h}$ sample, for which a large 
weight gain occurred, a strong peak from $\mathrm{Fe}_{2} \mathrm{O}_{3}$ is found showing that the alloy is no longer protected by the chromia. For the CGO coated sample (Figure $2 \mathrm{~B}$ and $\mathrm{E}$ ), strong peaks from the ceria coating are visible. Reference spectra (after $0 \mathrm{~h}$ - no oxidation) have very broad ceria peaks caused by the small crystallite size of the deposited layer. Already after $250 \mathrm{~h}$ oxidation grain growth has occurred and peaks are visibly narrower. In addition to a strong CGO signal, small peaks from $\mathrm{Cr}_{2} \mathrm{O}_{3}$ and $\mathrm{Mn}_{1.5} \mathrm{Cr}_{1.5} \mathrm{O}_{4}$ are detected. For the $\mathrm{Y}$ coated sample, $\mathrm{Y}_{2} \mathrm{O}_{3}$ is clearly visible on the as-prepared sample (Figure $2 \mathrm{C}$ and F). After oxidation for $250 \mathrm{~h}$ it is still visible, but peaks from a newly formed $\mathrm{YCrO}_{3}$ phase emerge. Thus, the yttria coating reacts with $\mathrm{Cr}$, forming the new perovskite phase. For the samples oxidized for $1000 \mathrm{~h}$ and $2000 \mathrm{~h}$, peaks from the yttria phase are no longer visible and peaks from the new perovskite phase have higher relative intensity. As shown later in the text, $\mathrm{YCrO}_{3}$ perovskite is a thermodynamically stable phase in the $\mathrm{Y}-\mathrm{Cr}-\mathrm{O}_{2}$ system, thus its forming is expected. In addition, peaks from $\mathrm{Cr}_{2} \mathrm{O}_{3}$ and $\mathrm{Mn}_{1.5} \mathrm{Cr}_{1.5} \mathrm{O}_{4}$ are present. The intensity of the $\mathrm{MnCr}$ spinel is visibly higher than the intensity from the $\mathrm{Cr}_{2} \mathrm{O}_{3}$ phase, whereas for the uncoated samples the intensity of chromia was higher.
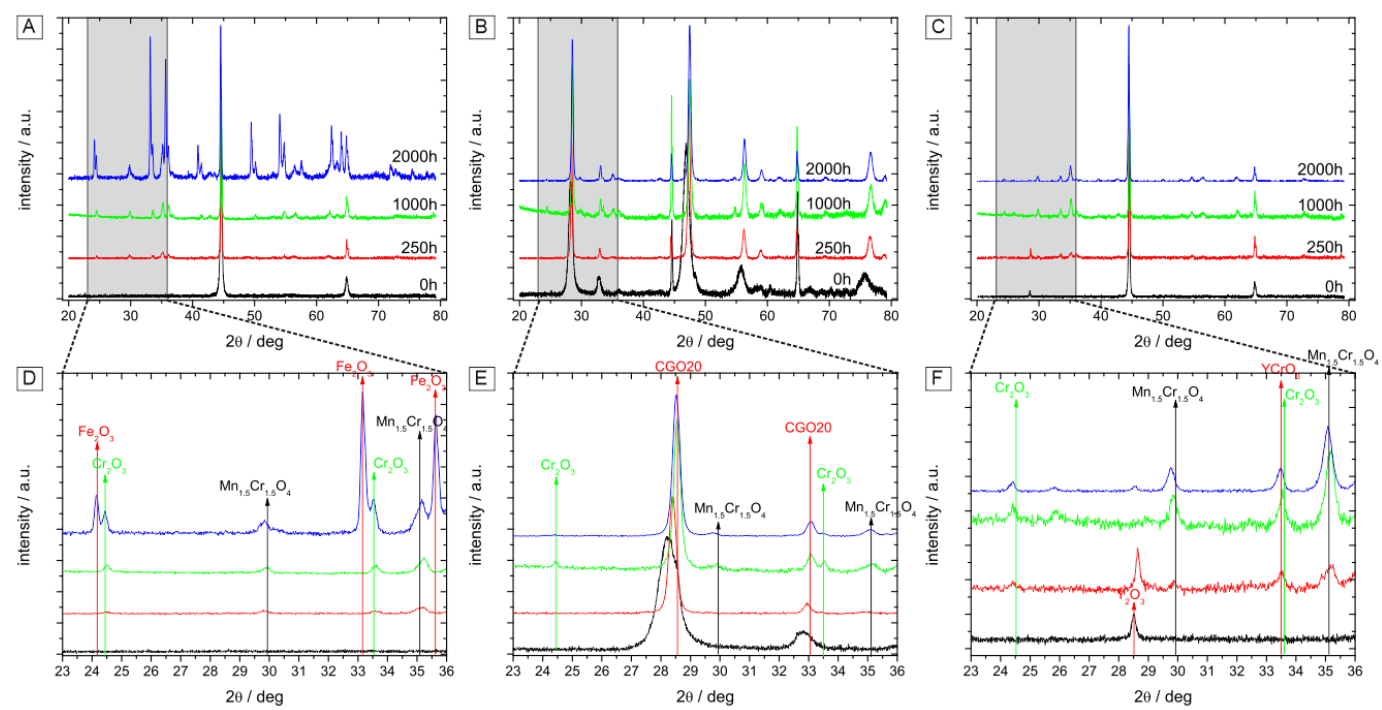

Figure 2. XRD of alloys after different corrosion exposures: A) uncoated alloy, B) CGO coated alloy, C) $\mathrm{Y}$-coated alloy. $\mathrm{D}, \mathrm{E}$ and $\mathrm{F}$ show a $23^{\circ}-36^{\circ} 2 \theta$ range for clarity.

The results of SEM observations on sample surfaces are summarized in Figure 3. Time development $(250 \mathrm{~h} \rightarrow 1000 \mathrm{~h} \rightarrow 2000 \mathrm{~h}$ ) of the surface is presented. The average chemical composition of the surface was also determined using EDS analysis and is given in Table 4. The signal from the full surface was used to average the composition.

For the uncoated samples (Figure $3 \mathrm{~A}, \mathrm{~B}, \mathrm{C}$ ), the surface seems to become more uniform with increasing oxidation time. After $250 \mathrm{~h}$ of oxidation some particles are sticking out from the surface, 
which after $1000 \mathrm{~h}$ seems quite porous. After $2000 \mathrm{~h}$, the surface seems to be much denser. Looking at the average chemical composition (Table 4), the detected Fe content decreases with time. Ratio of the $\mathrm{Mn} / \mathrm{Cr}$ is $\sim 1.5$, probably interfered by the chromia layer laying beneath.

After $250 \mathrm{~h}$ the surface of the CGO coated sample (Figure $3 \mathrm{D}$ ) is in a relatively good condition, and the CGO seems intact. However, after $1000 \mathrm{~h}$ (Figure $3 \mathrm{E}$ ), cracks become noticeable throughout the entire surface. When observed under an angle (Figure S2 in $\mathrm{SI}$ ), waviness of the surface was evident, showing buckling of the coating and possible poor adhesion. Also growth of $\mathrm{Mn}$ rich crystals is noticed. After $2000 \mathrm{~h}$ oxidation even more cracking occurred and spallation of large areas of the CGO layer are observed. Therefore the weight gains shown in Figure 1 and corrosion rates in Table 3 are clearly underestimated (material is lost from the sample surface by spallation). The chemical composition of the surface shows an increase in $\mathrm{Mn}$ and $\mathrm{Cr}$ content over time, probably due to an increased amount of $\mathrm{MnCr}$ crystals growing on top of the CGO coating. CGO has a large chemical expansion coefficient, when switching between the oxidizing and reducing atmospheres, together with a thermal expansion upon thermal cycles that might be the cause for the buckling and delamination of the coatings $[62,63]$.

The surface of the $\mathrm{Y}$-coated sample (Figure $3 \mathrm{G}, \mathrm{H}, \mathrm{I}$ ) appears very similar to the uncoated sample and crystallites growing from the surface are visible. In some places, a thicker Y-coating was deposited (as seen in Figure 6 A). In comparison to the uncoated sample, the surface did not densify over time. The Y-coat surface was uniform for all three samples and no defects were noticed. Analysis of the chemical composition shows a small amount of $Y$ present ( 1 at.\%) and an a $\mathrm{Mn} / \mathrm{Cr}$ ratio of $\sim 2$.

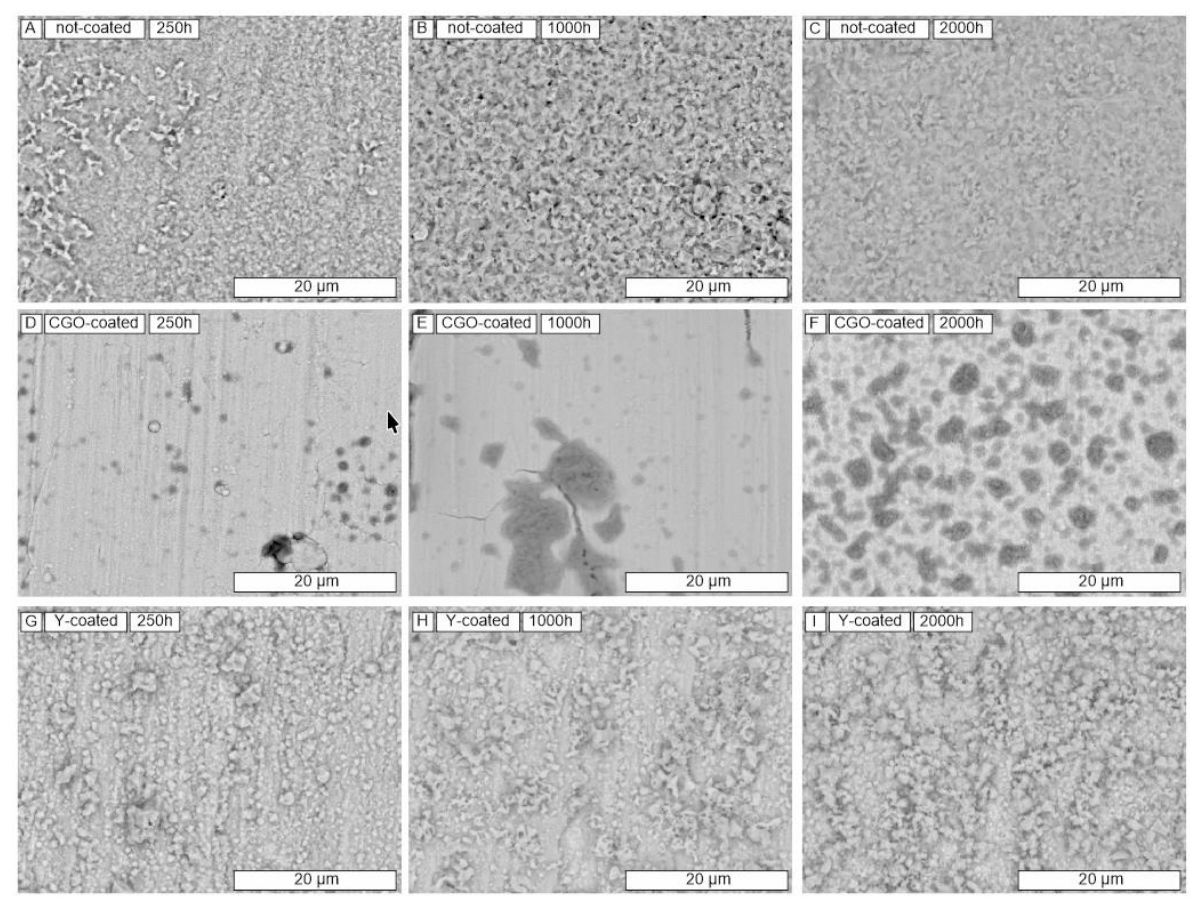

Figure 3. SEM images of sample surfaces after different oxidation times ( $250 \mathrm{~h} / 1000 \mathrm{~h} / 2000 \mathrm{~h})$. 
Table 4. Chemical compositions of sample surfaces after different oxidation times. EDS analyses were performed on images shown in Figure $3 \mathrm{~A}-\mathrm{I}$.

\begin{tabular}{|c|c|c|c|c|c|c|c|c|c|c|c|}
\hline & Fig.3: & at.\% & $\mathrm{Fe}$ & $\mathrm{Cr}$ & $\mathrm{Mn}$ & $\mathrm{Al}$ & $\mathrm{Ti}$ & $\mathrm{Ce}$ & $\mathrm{Gd}$ & $\mathrm{Y}$ & $\mathrm{O}$ \\
\hline \multirow{3}{*}{ Uncoated } & $\mathrm{A}$ & $250 \mathrm{~h}$ & 7.12 & 24.31 & 10.80 & 0.71 & 0.50 & - & - & - & 56.56 \\
\cline { 2 - 13 } & $\mathrm{B}$ & $100 \mathrm{~h}$ & 1.79 & 21.32 & 14.41 & 0.40 & 0.50 & - & - & - & 61.59 \\
\cline { 2 - 13 } & $\mathrm{C}$ & $2000 \mathrm{~h}$ & 3.03 & 21.82 & 14.47 & 0.76 & 0.49 & - & - & - & 59.43 \\
\hline \multirow{3}{*}{$\begin{array}{c}\text { CGO- } \\
\text { coated }\end{array}$} & $\mathrm{D}$ & $250 \mathrm{~h}$ & 2.16 & 1.83 & 0.89 & - & - & 33.15 & 3.16 & - & 58.80 \\
\cline { 2 - 12 } & $\mathrm{E}$ & $100 \mathrm{~h}$ & 1.39 & 2.13 & 5.46 & 0.82 & - & 25.37 & 2.37 & - & 62.43 \\
\cline { 2 - 12 } & $\mathrm{F}$ & $2000 \mathrm{~h}$ & 1.78 & 4.22 & 3.72 & 0.81 & - & 27.26 & 2.86 & - & 59.35 \\
\hline \multirow{3}{*}{ Y-coated } & $\mathrm{G}$ & $250 \mathrm{~h}$ & 16.68 & 19.99 & 10.48 & 0.13 & 0.58 & - & - & 1.25 & 50.89 \\
\cline { 2 - 12 } & $\mathrm{G}$ & $1000 \mathrm{~h}$ & 7.33 & 19.30 & 13.90 & - & 0.52 & - & - & 0.65 & 57.84 \\
\cline { 2 - 11 } & $\mathrm{I}$ & $2000 \mathrm{~h}$ & 6.04 & 21.77 & 11.25 & 0.27 & 0.47 & - & - & 1.86 & 58.34 \\
\hline
\end{tabular}

After performing the surface analysis, cross-sections of samples taken out of the furnace after $250 \mathrm{~h} / 1000 \mathrm{~h}$ and $2000 \mathrm{~h}$ were analyzed. Results are shown in Figure 4. In Figure 5 cross section obtained on areas where break away corrosion has taken place are reproduced. Clearly the uncoated sample shows the thickest oxide scale. After $2000 \mathrm{~h}$ it is 2-3 $\mu \mathrm{m}$ thick on average. Initially, after 250 $\mathrm{h}$, a thicker $\mathrm{Mn}-\mathrm{Cr}$ spinel grows on top a thin $\mathrm{Cr}_{2} \mathrm{O}_{3}$ scale. For $1000 \mathrm{~h}$ and $2000 \mathrm{~h}$ oxidation, the $\mathrm{Cr}_{2} \mathrm{O}_{3}-$ layer increases in thickness, with the the $\mathrm{Mn}-\mathrm{Cr}$ spinel appears also slightly growing. For the CGO coated sample, after $250 \mathrm{~h}$ the coating adheres well to the oxide, which is forming in between the coating and the steel. After $1000 \mathrm{~h}$, a detachment of CGO, almost on the full length of the interface, is visible. Only in very few spots, the CGO adheres to the oxide scale. The oxide scale is visibly thinner $(\sim 1 \mu \mathrm{m})$ in comparison to the uncoated sample. The oxide scale consists of internally growing $(\mathrm{Mn}, \mathrm{Cr})_{3} \mathrm{O}_{4}$ "pockets", which in this case are almost continuous.

For the $\mathrm{Y}$-coated sample, the oxide scale thickness is also lower than in the case for the uncoated sample. The coating itself is noticeable only in a few places (see also Figure 6). $\mathrm{MnCr}$ spinel large crystallites are growing from the surface. As is the case for the CGO coatings, thickness of the $\mathrm{Cr}_{2} \mathrm{O}_{3}$ layer is very low. 


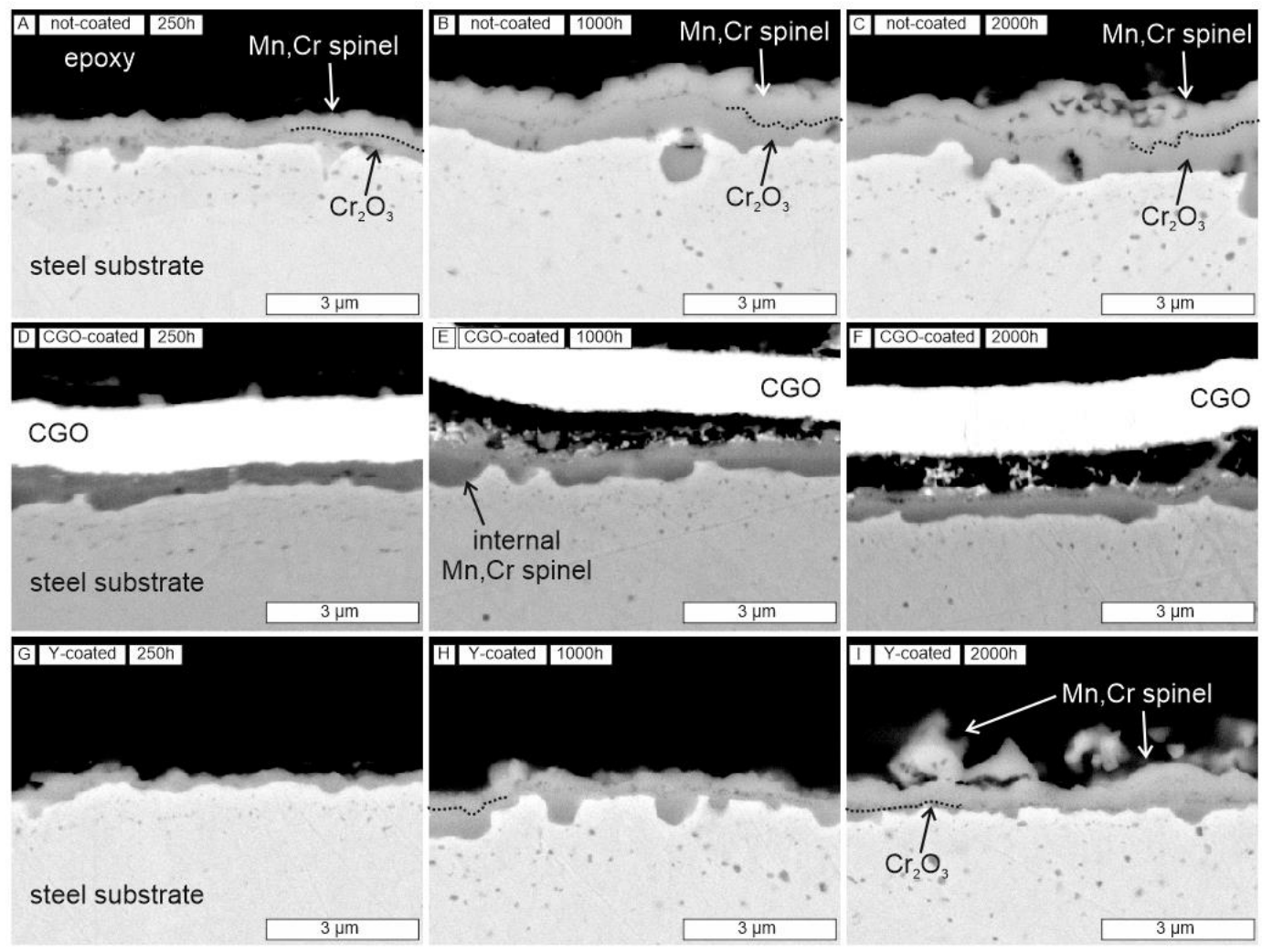

Figure 4. Overview SEM cross-section of A-C) uncoated, D-F) CGO-coated and G-I) Y-coated Crofer 22 APU steel after $250 \mathrm{~h}, 1000 \mathrm{~h}$, and $2000 \mathrm{~h}$ oxidation in $90 \% \mathrm{H}_{2} \mathrm{O}$ in $\mathrm{H}_{2}$ respectively.

Lower magnification SEM cross-sections with a longer length scale were obtained by combining several SEM images of the sample after $2000 \mathrm{~h}$ of oxidation This comparison of the corrosion effects on the three samples is shown in SI in Figure S3. The oxide is clearly visible on the uncoated sample. Also the formed oxide and the detachment of the CGO coating observed on the surface pictures is evident. Evidently this is not caused by metallographic preparation, as buckling was also seen from surface images and the coating is not cracked. CGO deformed either during the thermal cycling or more likely when stressed by the atmosphere change $\left(\mathrm{N}_{2} \rightarrow \mathrm{H}_{2} / \mathrm{H}_{2} \mathrm{O}\right.$ at $\left.750^{\circ} \mathrm{C}\right)$; CGO will expand on reduction [63]. For the Y-coated sample, the oxide scale is hardly visible at low magnification, confirming the good protective effect.

On all uncoated samples aged for $2000 \mathrm{~h}$ heavy corrosion was observed in many areas. This is illustrated by the cross sectional images reproduced in Figure 5 . Only on small parts of the area the preferred behavior, with a thin protective $\mathrm{Cr}_{2} \mathrm{O}_{3}$ layer underneath a $(\mathrm{Cr}, \mathrm{Mn})_{3} \mathrm{O}_{4}$ layer (as was illustrated in Figure 3 and 4) is observed. In many places, iron oxidized excessively and an internal oxide formation occurred. The oxides are visible up to $50 \mu \mathrm{m}$ in depth. Formed iron-rich oxide has a porous structure with a chemical composition of 44.98 at.\% Fe, 2.44 at.\% $\mathrm{Cr}, 1.10$ at.\% $\mathrm{Mn}$ and 51.48 at.\% O (integrated composition from Figure $5 \mathrm{C}$ ). Additional EDS analysis of the uncoated steel is 
included in Figure S4 and Table S1 in the SI. Analysis of the cross-section shows the porous oxide is a mixed $\mathrm{FeCr}$ oxide (composition of $\sim 24$ at.\% Fe, $\sim 20$ at.\% Cr, bal. O).
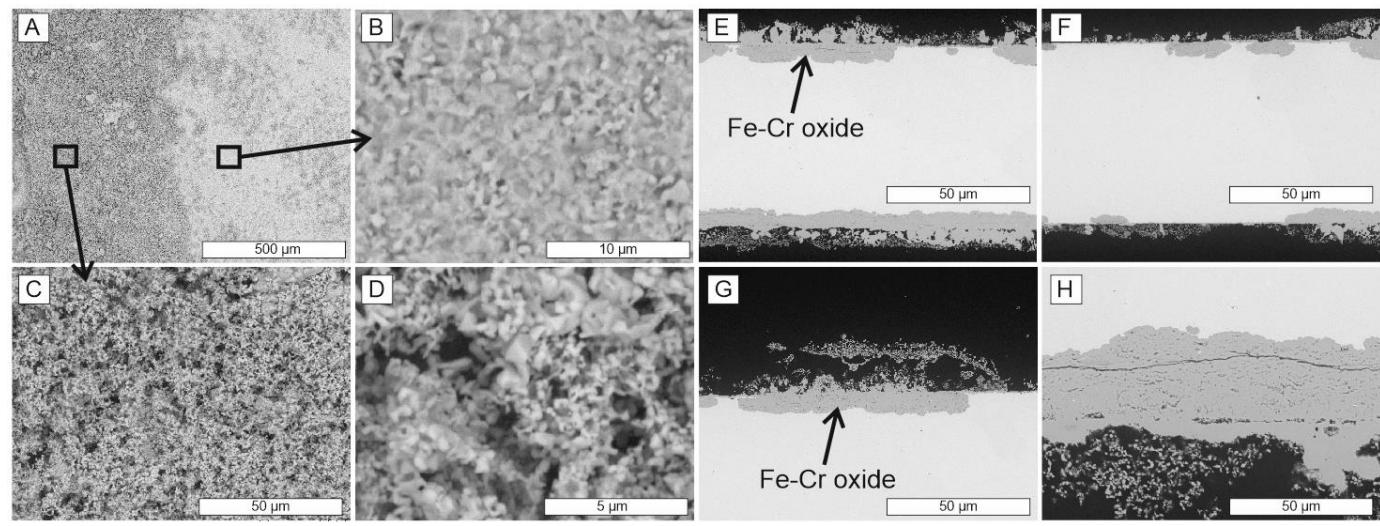

Figure 5. SEM images of heavily corroded uncoated Crofer 22 APU alloy after $2000 \mathrm{~h}$ oxidation in $90 \% \mathrm{H}_{2} \mathrm{O}$ in $\mathrm{H}_{2}$. A-D) surface, E-H) cross-section images.

A more detailed analysis of the $\mathrm{Y}$-coated steel after the oxidation is presented in Figure $6 \mathrm{~A}$. Elemental mapping shows $\mathrm{Y}$ to be present all over the surface but with some local enrichment. $\mathrm{Cr}$ is evenly distributed whereas $\mathrm{Mn}$ is found to be locally enriched in some areas in an island-like configuration (length-scale $\sim 5 \mu \mathrm{m}$ ). Average surface composition (determined by EDS) is given in Table 5. It is likely that a $\mathrm{MnCr}_{2} \mathrm{O}_{4}$ phase has formed. Figure $6 \mathrm{E}$ presents a higher magnification crosssection image. A bright line of the $\mathrm{Y}$-containing phase can be noticed on the oxide scale (along the $\mathrm{p} 2$, p3, p4 points). The point analyses at these locations confirm the presence of $Y$ in small amount. Points $\mathrm{p} 1$ and $\mathrm{p} 6$ consist of mostly oxygen and chromium, indicating formation of an inner layer of $\mathrm{Cr}_{2} \mathrm{O}_{3}$. Points p2, p3 and p4 contain (in addition to $\mathrm{Y}$ ) $12-15 \%$ of $\mathrm{Mn}$, so presence of a $\mathrm{Cr}$ rich spinel $(\mathrm{Mn}, \mathrm{Cr})_{3} \mathrm{O}_{4}$ is likely. The outermost analysed point $\mathrm{p} 5$ fits well with a $\mathrm{Mn}_{2} \mathrm{CrO}_{4}$ spinel. Looking at the cross-section, good adherence of the oxide scale to the alloy can be observed. No defects were noticed.
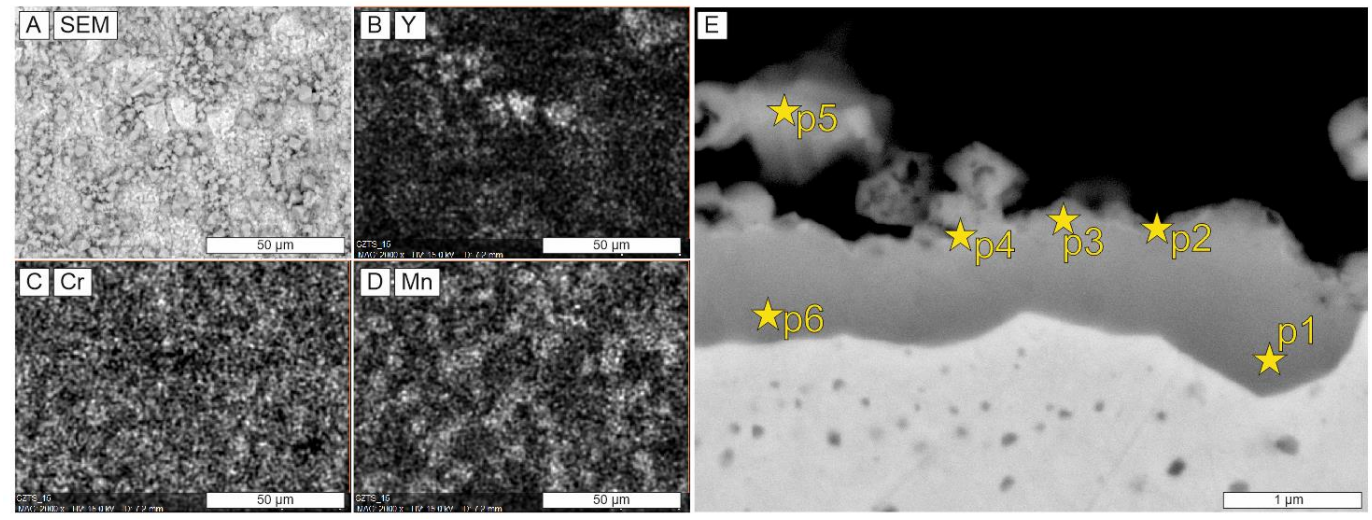
Figure 6. Surface SEM image (A) with elemental maps of $Y(B), C r(C), M n(D)$ and cross-section SEM image (E) of the $\mathrm{Y}$-coated steel after $2000 \mathrm{~h}$ oxidation in $90 \% \mathrm{H}_{2} \mathrm{O}$ in $\mathrm{H}_{2}$.

Table 5. Chemical composition (measured by EDS) of the surface (Figure $6 \mathrm{~A}$ ) and of the selected points in the cross-section (Figure $6 \mathrm{E}$ ).

\begin{tabular}{|c|c|c|c|c|c|c|c|}
\hline at.\% & $\mathrm{Fe}$ & $\mathrm{Cr}$ & $\mathrm{Mn}$ & $\mathrm{Al}$ & $\mathrm{Ti}$ & $\mathrm{Y}$ & $\mathrm{O}$ \\
\hline surface & 6.47 & 20.52 & 11.33 & & 0.46 & 2.36 & 58.85 \\
\hline $\mathrm{p} 1$ & 8.20 & 35.69 & 0.44 & - & 0.56 & - & 55.11 \\
\hline $\mathrm{p} 2$ & 2.26 & 30.98 & 12.00 & - & 0.62 & 1.71 & 52.43 \\
\hline $\mathrm{p} 3$ & 2.86 & 21.08 & 15.15 & - & 0.41 & 1.42 & 59.09 \\
\hline $\mathrm{p} 4$ & 3.27 & 21.60 & 12.58 & 0.22 & 0.51 & 1.92 & 59.90 \\
\hline $\mathrm{p} 5$ & 3.92 & 15.46 & 30.90 & 0.59 & 0.10 & 0.18 & 48.85 \\
\hline $\mathrm{p} 6$ & 3.21 & 33.70 & 3.14 & 0.24 & 0.8 & 0.09 & 58.73 \\
\hline
\end{tabular}

Proof of viability of the $Y$ coating; electrical characteristics

In order to prove the viability of the coating for use in SOFC/SOECS also electrical conductivity tests were performed. The developed coating process was also used to protect two types of steels in form of meshes, which can possibly be used for contacting and current collection between cells and interconnects in a stack. Due to a complex shape (Figure $7 \mathrm{~A}$, round cross-section) and a limited diameter $(\sim 30 \mu \mathrm{m})$, the chromium reservoir for forming a protective chromia scale is limited and scale adherence can be an issue due to the surface curvature. Reactive element coatings such as the one presented here is a possible route to alleviate these issues if providing sufficient reduction in corrosion rate and ensuring improved scale adhesion. The meshes were made from austenitic SUS316 and SUS316L grade steels (two from different producers, version "L" is a low carbon content alloy). The Y-coating was made with the same parameters as were used for the flat plates, i.e. no optimization of the coating procedure was performed. Meshes were tested for their electrical conductivity at $650{ }^{\circ} \mathrm{C}$ in air and hydrogen/steam $\left(90 \% \mathrm{H}_{2} \mathrm{O}\right.$ in $\left.\mathrm{H}_{2}\right)$. In the measurements electrical current is passed across the plane of the mesh (perpendicular to the fibers) thus passing over the surface scale. A clear positive effect of the Y-coating on the effective cross sample (cross scale) conductance is evident form the results depicted in Figure 7. Only the Y-coated meshes retain a low Area Specific Resistance (ASR), proving that the protective action of the coating is not associated with any adverse effects on the cross-scale-conductivity. This is observed in both air and in hydrogen/steam. In contrast, steel meshes with no coating corroded heavily, as seen from the increase in ASR in Figure $7 \mathrm{~A}$. Post-test SEM analysis revealed good adherence of the oxide scale and moderate oxide thickness, as observed in Figure $7 \mathrm{C}$, whereas the uncoated alloys were corroded to a much greater extent, as shown in Figure $7 \mathrm{D}$. 

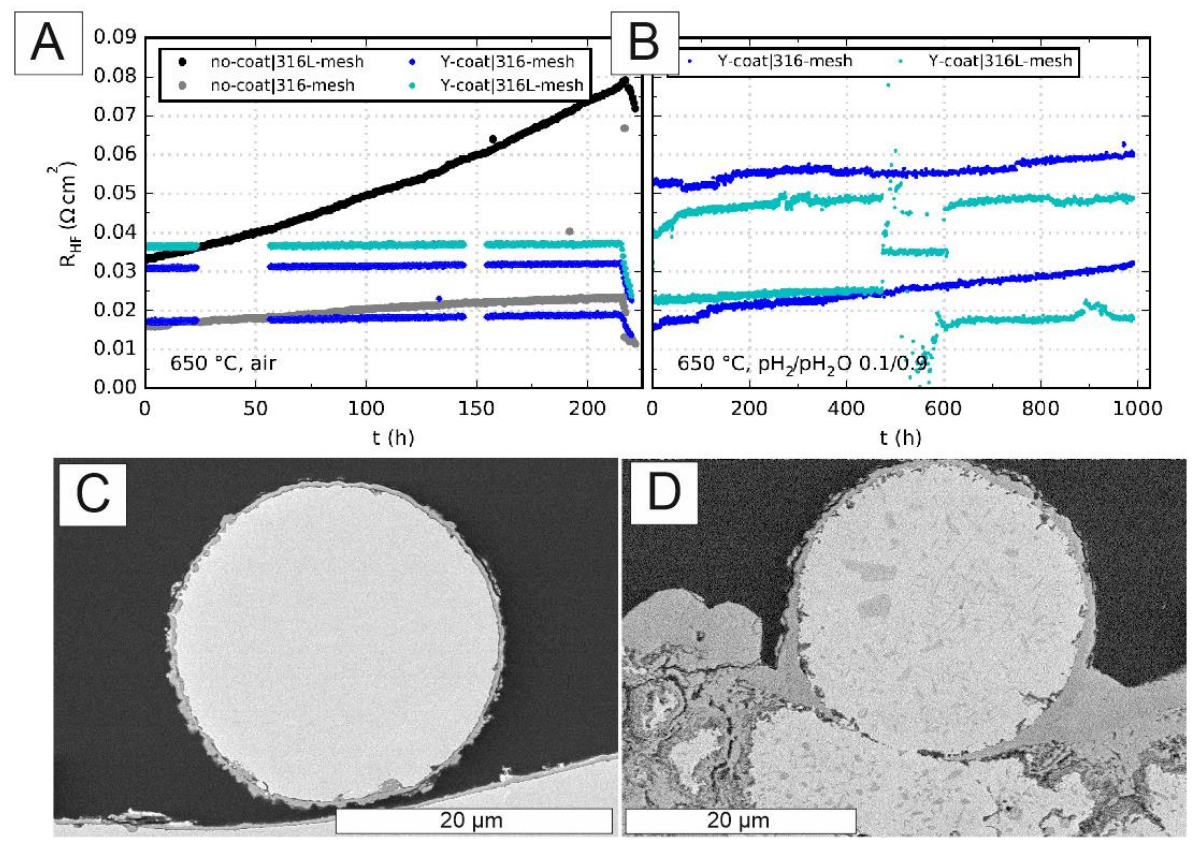

Figure 7. "Area Specific Resistance" (cross sample resistance/total sample area) of SUS316 and SUS316L meshes in air (A) and hydrogen/steam (B). Post-mortem SEM cross-sections of a Y-coated SUS316L mesh after test in reducing atmosphere (C), and a non-coated SUS316 mesh after test in air (D).

\section{Thermodynamic considerations}

In order to evaluate the thermodynamic stability of the formed $\mathrm{Y}$-Cr-reaction products, especially in the context of long term stability, a $\mathrm{Y}-\mathrm{Cr}-\mathrm{O}_{2}$ phase diagram was constructed. Figure $8 \mathrm{~B}$ presents the calculated phase diagrams of $\mathrm{Y}_{2} \mathrm{O}_{3}-\mathrm{Cr}_{2} \mathrm{O}_{3}$ in air, showing that $\mathrm{YCrO}_{3}$ is stable all the way up to its melting point $\left(2300{ }^{\circ} \mathrm{C}\right) . \mathrm{YCrO}_{3}$ is stable also in the $\mathrm{pO}_{2}$ characteristic of the fuel side in SOFC/SOECs. Figure $8 \mathrm{~A}$ shows the calculated isothermal $\mathrm{pO}_{2}$-composition phase diagram at $750{ }^{\circ} \mathrm{C} . \mathrm{YCrO}_{3}$ is stable down to $\mathrm{pO}_{2}=10^{-34.1}$ bar, under which it decomposes into $\mathrm{Y}_{2} \mathrm{O}_{3}, \mathrm{Cr}$ metal, and oxygen. $\mathrm{Y}_{2} \mathrm{O}_{3}$ is then reduced to $\mathrm{Y}$ metal and oxygen when the oxygen partial pressure is further reduced.

As confirmed by XRD in this work, $\mathrm{YCrO}_{3}$ forms due to reaction of the coating material $\left(\mathrm{Y}_{2} \mathrm{O}_{3}\right)$ with chromium from chromia. Though possibly also other oxides might form between the coating material and the available element (i.e. $\mathrm{YMnO}_{3}$ ), large amount of available $\mathrm{Cr}$ and high stability of the $\mathrm{YCrO}_{3}$ phase look promising for long term application. 

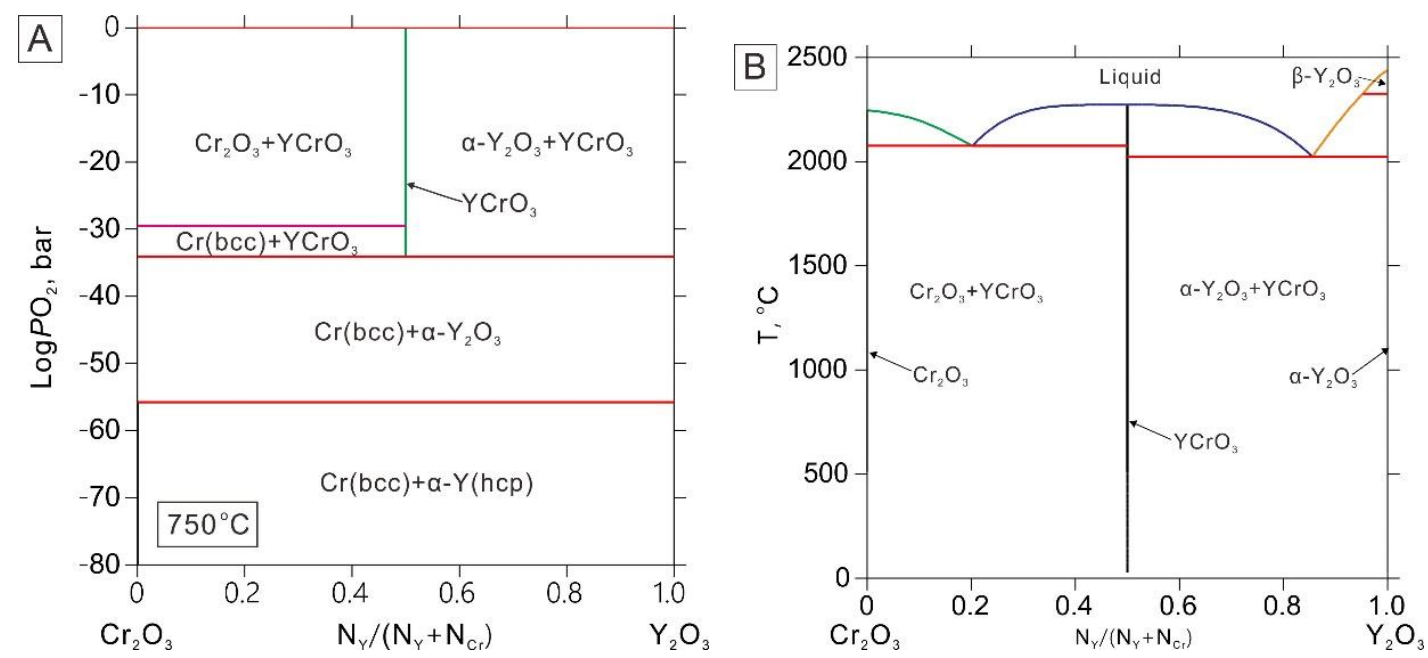

Figure 8. Calculated isothermal $\mathrm{pO}_{2}$-composition phase diagram at $750{ }^{\circ} \mathrm{C}(\mathrm{A})$, and calculated phase diagram of $\mathrm{Cr}_{2} \mathrm{O}_{3}-\mathrm{Y}_{2} \mathrm{O}_{3}$ in air (B).

\section{Conclusions}

High temperature corrosion of steel interconnects in SOFC/SOEC-stacks is an important engineering challenge. As shown in this work, uncoated alloys corroded heavily in $90 \% / 10 \%$ steam-hydrogen mixtures at $750{ }^{\circ} \mathrm{C}$. Electrodeposited thin Y-coatings (thickness less than $100 \mathrm{~nm}$ ) proved to be effective in protecting the surface of both the Crofer 22 APU steel sheets and SUS316 and SUS316L meshes in corrosive atmospheres. Initially formed electrically insulating $\mathrm{Y}_{2} \mathrm{O}_{3}$ reacts with $\mathrm{Cr}$ and forms a better conducting and very stable $\mathrm{YCrO}_{3}$ phase. The simple application process is well suited for coating of even complex geometries and it results in both reduction of oxide scale thickness and in high, stable electrical conductivity (tracked over $1000 \mathrm{hr}$ ). Further, as shown by thermodynamic modelling, $\mathrm{YCrO}_{3}$ is a very stable phase.

The proposed Y-coating holds a great potential for practical application in solid oxide cell stack interconnects. The simplicity of the proposed coating procedure, the ability to coat even complex structures and the low amount of material used are important technical features. More details about the protective nature of the $\mathrm{Y}$-coatings prepared by the electrolytic deposition on different alloys and oxidized at different atmospheres will be presented in future.

\section{Acknowledgments}

Funding from the project ForskEl 2015-1-12276 "Towards solid oxide electrolysis plants in 2020" (energienet.dk, the "Forskel"-program) and the project from the Energy Technology Development and Demonstration Program (EUDP) via project no. 64015-0523 "Maturing SOEC" are gratefully acknowledged. SM further acknowledges the Statutory Funds from the Faculty of Electronics, Telecommunications and Informatics, Gdansk University of Technology, Poland. 


\section{References}

[1] N. Shaigan, W. Qu, D.G. Ivey, W. Chen, A review of recent progress in coatings, surface modifications and alloy developments for solid oxide fuel cell ferritic stainless steel interconnects, J. Power Sources. 195 (2010) 1529-1542.

[2] P. Piccardo, R. Amendola, S. Fontana, S. Chevalier, G. Caboches, P. Gannon, Interconnect materials for next-generation solid oxide fuel cells, J. Appl. Electrochem. 39 (2009) 545-551. doi:10.1007/s10800-008-9743-8.

[3] J. Yang, W. Huang, X. Wang, J. Li, D. Yan, J. Pu, B. Chi, J. Li, Study on component interface evolution of a solid oxide fuel cell stack after long term operation, J. Power Sources. 387 (2018) 57-63. doi:10.1016/j.jpowsour.2018.03.040.

[4] J. Li, W. Zhang, J. Yang, D. Yan, J. Pu, B. Chi, L. Jian, Oxidation behavior of metallic interconnect in solid oxide fuel cell stack, J. Power Sources. 353 (2017) 195-201. doi:10.1016/j.jpowsour.2017.03.092.

[5] P. Alnegren, M. Sattari, J. Froitzheim, J.E. Svensson, Degradation of ferritic stainless steels under conditions used for solid oxide fuel cells and electrolyzers at varying oxygen pressures, Corros. Sci. 110 (2016) 200-212. doi:10.1016/j.corsci.2016.04.030.

[6] S. Molin, M. Chen, P.V. Hendriksen, Oxidation study of coated Crofer 22 APU steel in dry oxygen, J. Power Sources. 251 (2013) 488-495. doi:10.1016/j.jpowsour.2013.09.100.

[7] M. Palcut, L. Mikkelsen, K. Neufeld, M. Chen, R. Knibbe, P.V. Hendriksen, Corrosion stability of ferritic stainless steels for solid oxide electrolyser cell interconnects, Corros. Sci. 52 (2010) 3309-3320.

[8] J.W. Fergus, Metallic interconnects for solid oxide fuel cells, Mater. Sci. Eng. A. 397 (2005) 271-283.

[9] X. Montero, F. Tietz, D. Sebold, H.P. Buchkremer, A. Ringuede, M. Cassir, A. Laresgoiti, I. Villarreal, MnCo1.9Fe0.104 spinel protection layer on commercial ferritic steels for interconnect applications in solid oxide fuel cells, J. Power Sources. 184 (2008) 172-179. doi:10.1016/j.jpowsour.2008.05.081.

[10] B. Talic, H. Falk-Windisch, V. Venkatachalam, P.V. Hendriksen, K. Wiik, H.L. Lein, Effect of coating density on oxidation resistance and $\mathrm{Cr}$ vaporization from solid oxide fuel cell interconnects, J. Power Sources. 354 (2017) 57-67. doi:10.1016/j.jpowsour.2017.04.023.

[11] N. Grünwald, D. Sebold, Y.J. Sohn, N.H. Menzler, R. Vaßen, Self-healing atmospheric plasma sprayed $\mathrm{Mn}<$ inf $>1.0</$ inf $>$ Co $<$ inf $>1.9</$ inf $>$ Fe $<$ inf $>0.1</$ inf $>0<$ inf $>4</$ inf $>$ protective interconnector coatings for solid oxide fuel cells, J. Power Sources. 363 (2017) 185-192. 
doi:10.1016/j.jpowsour.2017.07.072.

[12] S. Molin, P. Jasinski, L. Mikkelsen, W. Zhang, M. Chen, P.V.P.V. Hendriksen, Low temperature processed $\mathrm{MnCo} 2 \mathrm{O} 4$ and $\mathrm{MnCo1.8Fe0.2O4} \mathrm{as} \mathrm{effective} \mathrm{protective} \mathrm{coatings} \mathrm{for} \mathrm{solid} \mathrm{oxide} \mathrm{fuel}$ cell interconnects at $750{ }^{\circ} \mathrm{C}$, J. Power Sources. 336 (2016) 408-418. doi:10.1016/j.jpowsour.2016.11.011.

[13] Å.H. Persson, L. Mikkelsen, P.V. Hendriksen, M.A.J. Somers, Interaction mechanisms between slurry coatings and solid oxide fuel cell interconnect alloys during high temperature oxidation, J. Alloys Compd. 521 (2012) 16-29. doi:10.1016/j.jallcom.2011.12.095.

[14] J.G. Grolig, J. Froitzheim, J.-E. Svensson, Coated stainless steel 441 as interconnect material for solid oxide fuel cells: Evolution of electrical properties, J. Power Sources. 284 (2015) 321327. doi:10.1016/j.jpowsour.2015.03.029.

[15] S. Chevalier, What did we learn on the reactive element effect in chromia scale since Pfeil 's patent?, Mater. Corros. 65 (2014) 109-115. doi:10.1002/maco.201307310.

[16] F. Riffard, H. Buscail, E. Caudron, R. Cueff, C. Issartel, S. Perrier, Yttrium implantation effect on $304 \mathrm{~L}$ stainless steel high temperature oxidation at $1000^{\circ} \mathrm{C}$, J. Mater. Sci. 37 (2002) 3925-3933. doi:10.1023/A:1019667825476.

[17] R. Cueff, H. Buscail, E. Caudron, F. Riffard, C. Issartel, S. El Messki, Effect of reactive element oxide coating on the high temperature oxidation behaviour of FeCrAl alloys, Appl. Surf. Sci. 229 (2004) 233-241. doi:10.1016/j.apsusc.2004.01.072.

[18] F. Riffard, H. Buscail, E. Caudron, R. Cueff, C. Issartel, S. Perrier, Yttrium sol-gel coating effects on the cyclic oxidation behaviour of 304 stainless steel, Corros. Sci. 45 (2003) 2867-2880. doi:10.1016/S0010-938X(03)00114-8.

[19] S. Fontana, R. Amendola, S. Chevalier, P. Piccardo, G. Caboche, M. Viviani, R. Molins, M. Sennour, Metallic interconnects for SOFC: Characterisation of corrosion resistance and conductivity evaluation at operating temperature of differently coated alloys, J. Power Sources. 171 (2007) 652-662. doi:10.1016/j.jpowsour.2007.06.255.

[20] A. Gil, J. Wyrwa, T. Brylewski, Improving the Oxidation Resistance and Electrical Properties of Ferritic Stainless Steels for Application in SOFC Interconnects, Oxid. Met. 85 (2016) 151-169. doi:10.1007/s11085-015-9605-9.

[21] T. Brylewski, A. Gil, A. Rakowska, S. Chevalier, A. Adamczyk, J. Dabek, A. Kruk, M. Stygar, K. Przybylski, Improving the Physicochemical Properties of Fe-25Cr Ferritic Steel for SOFC Interconnects via Y-Implantation and Y2O3-Deposition, Oxid. Met. 80 (2012) 83-111. doi:10.1007/s11085-012-9345-z.

[22] E. Tondo, M. Boniardi, D. Cannoletta, M.F. De Riccardis, B. Bozzini, Electrodeposition of yttria/cobalt oxide and yttria/gold coatings onto ferritic stainless steel for SOFC interconnects, 
J. Power Sources. 195 (2010) 4772-4778. doi:10.1016/j.jpowsour.2010.02.055.

[23] I. Zhitomirsky, A. Petric, Electrolytic and electrophoretic deposition of $\mathrm{CeO} 2$ films, Mater. Lett. 40 (1999) 263-268. doi:10.1016/S0167-577X(99)00087-7.

[24] A.R. Boccaccini, I. Zhitomirsky, Application of electrophoretic and electrolytic deposition techniques in ceramics processing, Curr. Opin. Solid State Mater. Sci. 6 (2002) 251-260. doi:10.1016/S1359-0286(02)00080-3.

[25] I. Zhitomirsky, A. Petric, Electrochemical deposition of yttrium oxide, J. Mater. Chem. 10 (2000) 1215-1218. doi:10.1039/b000311p.

[26] I. Zhitomirsky, Cathodic electrodeposition of ceramic and organoceramic materials. Fundamental aspects, Adv. Colloid Interface Sci. 97 (2002) 279-317.

[27] P. Alnegren, M. Sattari, J.-E. Svensson, J. Froitzheim, Severe dual atmosphere effect at $600{ }^{\circ} \mathrm{C}$ for stainless steel 441, J. Power Sources. 301 (2016) 170-178. doi:10.1016/j.jpowsour.2015.10.001.

[28] D. Szymczewska, S. Molin, M. Chen, P.V. Hendriksen, P. Jasinski, Ceria Based Protective Coatings for Steel Interconnects Prepared by Spray Pyrolysis, Procedia Eng. 98 (2014) 93-100. doi:10.1016/j.proeng.2014.12.493.

[29] L. Garcia-Fresnillo, V. Shemet, A. Chyrkin, L.G.J. de Haart, W.J. Quadakkers, Long-term behaviour of solid oxide fuel cell interconnect materials in contact with $\mathrm{Ni}$-mesh during exposure in simulated anode gas at 700 and $800^{\circ} \mathrm{C}$, J. Power Sources. 271 (2014) 213-222. doi:10.1016/j.jpowsour.2014.07.189.

[30] T. Brylewski, J. Dabek, K. Przybylski, J. Morgiel, M. Rekas, Screen-printed (La,Sr)CrO3 coatings on ferritic stainless steel interconnects for solid oxide fuel cells using nanopowders prepared by means of ultrasonic spray pyrolysis, J. Power Sources. 208 (2012) 86-95. doi:10.1016/j.jpowsour.2012.02.015.

[31] M. del M. Juez Lorenzo, V. Kolarik, V. Kuchenreuther-Hummel, M. Pötschke, D. Schimanke, Oxidation of La-Sr-Mn-Coated Interconnector Alloys for Steam Electrolysis Under Pressure in Pure Oxygen and in Pure Steam, Oxid. Met. (2017) 1-12. doi:10.1007/s11085-017-9736-2.

[32] M.R. Ardigo, I. Popa, S. Chevalier, P. Girardon, F. Perry, R. Laucournet, A. Brevet, C. Desgranges, Effect of coatings on long term behaviour of a commercial stainless steel for solid oxide electrolyser cell interconnect application in $\mathrm{H} 2 / \mathrm{H} 2 \mathrm{O}$ atmosphere, Int. J. Hydrogen Energy. 39 (2014) 21673-21677. doi:10.1016/j.ijhydene.2014.07.058.

[33] M.R. Ardigo, I. Popa, S. Chevalier, V. Parry, A. Galerie, P. Girardon, F. Perry, R. Laucournet, A. Brevet, E. Rigal, Coated interconnects development for high temperature water vapour electrolysis: Study in anode atmosphere, Int. J. Hydrogen Energy. 38 (2013) 15910-15916. doi:10.1016/j.ijhydene.2013.10.026. 
[34] J. Froitzheim, L. Niewolak, M. Brandner, L. Singheiser, W.J. Quadakkers, Anode Side Diffusion Barrier Coating for Solid Oxide Fuel Cells Interconnects, J. Fuel Cell Sci. Technol. 7 (2010) 031020-7. doi:10.1115/1.3182731.

[35] D. Szymczewska, S. Molin, M. Chen, P.J. Ski, P.V. Hendriksen, Corrosion study of ceria protective layer deposited by spray pyrolysis on steel interconnects, in: Ceram. Eng. Sci. Proc., 2017. doi:10.1002/9781119320197.ch7.

[36] S. Molin, M. Chen, J.R. Bowen, P.V. Hendriksen, Diffusion of nickel into ferritic steel interconnects of solid oxide fuel/electrolysis stacks, ECS Trans. 57 (2013) 2245-2252.

[37] M. Chen, S. Molin, L. Zhang, N. Ta, P.V. Hendriksen, W.-R. Kiebach, Y. Du, Modeling of Ni Diffusion Induced Austenite Formation in Ferritic Stainless Steel Interconnects, ECS Trans. . 68 (2015) 1691-1700. doi:10.1149/06801.1691ecst.

[38] L. Garcia-Fresnillo, R. Patel, L. Niewolak, W.J. Quadakkers, M. Hua, Q. Wang, G.H. Meier, Oxidation behaviour and phase transformations of an interconnect material in simulated anode environment of intermediate temperature solid oxide fuel cells, Mater. High Temp. 34 (2017) 61-77. doi:10.1080/09603409.2016.1244373.

[39] K.A. Nielsen, A.R. Dinesen, L. Korcakova, L. Mikkelsen, P. V Hendriksen, F.W. Poulsen, Testing of Ni-Plated Ferritic Steel Interconnect in SOFC Stacks, Fuel Cells. 6 (2006) 100-106. doi:10.1002/fuce.200500114.

[40] J.V.T. Høgh, L. Mikkelsen, P. Vang Hendriksen, Interface resistance between FeCr interconnects and Ni/YSZ, Proc. 8th Eur. Solid Oxide Fuel Cells Forum. (2008) 10.

[41] E. Sarasketa-Zabala, L. Otaegi, L.M. Rodriguez-Martinez, M.A. Alvarez, N. Burgos, F. Castro, I. Villarreal, High temperature stability of porous metal substrates under highly humidified hydrogen conditions for metal supported Solid Oxide Fuel Cells, Solid State Ionics. 222-223 (2012) 16-22. doi:10.1016/j.ssi.2012.06.014.

[42] C. Folgner, V. Sauchuk, M. Kusnezoff, A. Michaelis, Interconnect corrosion in steam containing fuel gas, ECS Trans. 78 (2017) 1543-1558.

[43] D.M. England, A. V. Virkar, Oxidation Kinetics of Some Nickel-Based Superalloy Foils in Humidified Hydrogen and Electronic Resistance of the Oxide Scale Formed Part II, J. Electrochem. Soc. 148 (2001) A330. doi:10.1149/1.1354611.

[44] S. Sønderby, P.L. Popa, J. Lu, B.H. Christensen, K.P. Almtoft, L.P. Nielsen, P. Eklund, Strontium Diffusion in Magnetron Sputtered Gadolinia-Doped Ceria Thin Film Barrier Coatings for Solid Oxide Fuel Cells, Adv. Energy Mater. 3 (2013) 923-929. doi:10.1002/aenm.201300003.

[45] S. Sønderby, T. Klemens $\varnothing$, B.H. Christensen, K.P. Almtoft, J. Lu, L.P. Nielsen, P. Eklund, Magnetron sputtered Gadolinia-doped Ceria Diffusion Barriers for Metal-supported Solid Oxide Fuel Cells, J. Power Sources. 267 (2014) 452-458. doi:10.1016/j.jpowsour.2014.05.101. 
[46] T. Klemensø, J. Nielsen, P. Blennow, Å.H. Persson, T. Stegk, B.H. Christensen, S. Sønderby, High performance metal-supported solid oxide fuel cells with Gd-doped ceria barrier layers, J. Power Sources. 196 (2011) 9459-9466. doi:10.1016/j.jpowsour.2011.07.014.

[47] E. Povoden, A.N. Grundy, L.J. Gauckler, Thermodynamic reassessment of the Cr-O system in the framework of Solid Oxide Fuel Cell (SOFC) research, J. Phase Equilibria Diffus. 27 (2006) 353-362. doi:10.1361/154770306X116289.

[48] M. Chen, B. Hallstedt, L.J. Gauckler, Thermodynamic modeling of the ZrO2-YO1.5system, Solid State lonics. 170 (2004) 255-274. doi:10.1016/j.ssi.2004.02.017.

[49] A.G. Stoppe, L.M. Khriplovich, A.. Vorob'ev, Heat capacity of Ysub(1-x)Casub(x)CrOsub(3) in the temperature interval of 4.6-310 K, Zh. Fiz. Khim. (Russian J. Phys. Chem. 55 (1981) 248249.

[50] A.G. Stoppe, L.M. Khriplovich, A.. Vorob'ev, Thermodynamic functions of yttrium chromite in the temperature range of 5-310K, Zh. Fiz. Khim. (Russian J. Phys. Chem. 57 (1983) 239-244.

[51] H. Yokokawa, N. Sakai, T. Kawada, M. Dokiya, Chemical Thermodynamic Considerations in Sintering of LaCrO[sub 3]-Based Perovskites, J. Electrochem. Soc. 138 (1991) 1018. doi:10.1149/1.2085708.

[52] H. Satoh, S. Koseki, M. Takagi, Won Yang Chung, N. Kamegashira, Heat capacities of LnCrO3 (Ln=rare earth), J. Alloys Compd. 259 (1997) 176-182. doi:10.1016/S0925-8388(97)00053-4.

[53] J.W. Kim, Y.S. Oh, K.S. Suh, Y.D. Park, K.H. Kim, Specific heat of a YCrO3 single crystal as investigated by a Si-N membrane based microcalorimeter, Thermochim. Acta. 455 (2007) 2-6. doi:10.1016/j.tca.2006.12.007.

[54] Y. Su, L. Li, Z. Xing, Z. Feng, D. Deng, B. Kang, S. Cao, J. Zhang, Study of magnetism and specificheat properties for multiferroic YCrO3chromites, 2011 Int. Symp. Appl. Ferroelectr. 2011 Int. Symp. Piezoresponse Force Microsc. Nanoscale Phenom. Polar Mater. ISAF/PFM 2011. (2011) 3-6. doi:10.1109/ISAF.2011.6014122.

[55] Y.L. Suponitskii, Thermal properties and thermochemistry of lanthanide chromates, Russ. Chem. Bull. 54 (2005) 294-299. doi:10.1007/s11172-005-0251-2.

[56] K.I. Kawamura, T. Maruyama, K. Nagata, The equilibrium oxygen pressure over the Cr-Y2O3YCrO3 coexistence measured with the galvanic cell using stabilized $\mathrm{ZrO} 2$ solid electrolyte, Metall. Mater. Trans. B. 26 (1995) 289-294. doi:10.1007/BF02660971.

[57] S. Ranganathan, D. Janke, Thermodynamics of Some New Oxide Reference Materials for Electrochemical Oxygen Sensors, Scr. Metall. Mater. 29 (1993) 305-310.

[58] H. Xu, M. Chen, K. Cheng, L. Zhang, Y. Du, Thermodynamic modelling of the chromiumyttrium-oxygen system, Calphad. 64C (2019).

[59] W. Zhang, B. Hua, J. Yang, B. Chi, J. Pu, L. Jian, Performance evaluation of a new Fe-Cr-Mn 
alloy in the reducing atmosphere of solid oxide fuel cells, J. Alloys Compd. 769 (2018) 866872. doi:10.1016/j.jallcom.2018.08.002.

[60] B. Talic, S. Molin, K. Wiik, P.V.P.V. Hendriksen, H.L. Lein, Comparison of iron and copper doped manganese cobalt spinel oxides as protective coatings for solid oxide fuel cell interconnects, J. Power Sources. 372 (2017) 145-156. doi:10.1016/j.jpowsour.2017.10.060.

[61] S. Molin, M. Chen, J.J.J. Bentzen, P.V. V. Hendriksen, High Temperature Oxidation of Ferritic Steels for Solid Oxide Electrolysis Stacks, ECS Trans. 50 (2013) 11-20. doi:10.1149/05030.0011ecst.

[62] M. Mogensen, N.M. Sammes, G.A. Tompsett, Physical, chemical and electrochemical properties of pure and doped ceria, Solid State lonics. 129 (2000) 63-94. doi:10.1016/S01672738(99)00318-5.

[63] C. Chatzichristodoulou, P. Norby, P. V. Hendriksen, M.B. Mogensen, Size of oxide vacancies in fluorite and perovskite structured oxides, J. Electroceramics. 34 (2015) 100-107. doi:10.1007/s10832-014-9916-2. 